Cuadernos de Historia Contemporánea

ISSN: 0214-400X

http://dx.doi.org/10.5209/CHCO.56266

\title{
La reivindicación de la nación civilizada: masculinidad española en el discurso colonial sobre Marruecos (1900-1927) ${ }^{1}$
}

\author{
Gemma Torres ${ }^{2}$
}

Recibido: 17 de octubre de 2016 / Aceptado: 23 de marzo de 2017

Resumen. El presente trabajo analiza cómo en el marco del discurso colonial español en Marruecos se discutía y construía la identidad nacional. Algunos sectores impulsores de la colonización reivindicaron que España era y debía ser una nación civilizada en un periodo en el que su pertenencia al mundo de la modernidad estaba en duda. Era tildada de nación decadente y semiafricana. Se estudiará cómo esta reflexión sobre la identidad nacional se vehiculó a través de los valores y las imágenes de la virilidad. Para ello, se analizarán los arquetipos masculinos españoles -y marroquíes- que se dibujaron en los discursos coloniales creados en España sobre Marruecos en el periodo de las guerras del Rif (1909-1927). Palabras clave: Colonialismo; Marruecos; masculinidad; identidad nacional; guerras del Rif.

\section{[en] The Claim of the Civilized Nation: Spanish Masculinity in Colonial Discourse about Morocco (1900-1927)}

\begin{abstract}
This paper analyzes how Spanish national identity was discussed and constructed in Spanish colonial discourse about Morocco. Some colonial sectors claimed that Spain was and should be a civilized nation in a period during which doubt was cast on its status as a modern nation. Spain was described as a decadent, almost African nation. This article will examine how national identity was discussed through the values and images of manhood. To do so, it will analyze the male archetypes -Spanish and Moroccan- drawn in colonial discourses created in Spain about Morocco during the Rif wars (1909-1927).
\end{abstract}

Keywords: Colonialism; Morocco; masculinity; national identity; Rif wars.

Sumario. 1. Civilización y angustia nacional en el colonialismo español en Marruecos 2. El conquistador español. 3. El hombre marroquí. 4. El colonizador español como padre. 5. Civilización, masculinidad, nación.

Cómo citar: Torres, G. (2017). "La reivindicación de la nación civilizada: masculinidad española en el discuro colonial sobre Marruecos (1900-1927)". Cuadernos de Historia Contemporánea, 39, 59-81.

1 Este trabajo se inscribe en el proyecto HAR2013-45840-R, financiado por el Ministerio de Economía y Competitividad.

2 Universitat de Barcelona (España)

E-mail: gemmatorresdelgado@ub.edu 


\section{Civilización y angustia nacional en el colonialismo español en Marruecos}

Los proyectos coloniales fueron escenarios privilegiados en los procesos de construcción nacional. En el marco de los discursos coloniales se discutía y se afirmaba la identidad metropolitana. En este sentido, en el discurso colonial sobre Marruecos cristalizaron una serie de ansiedades sobre la identidad nacional española en relación a las ideas de civilización, europeidad y modernidad. Este artículo analizará cómo los valores y las imágenes de la masculinidad vehicularon estas ansiedades a través del estudio de los arquetipos masculinos - españoles y marroquíes- que se dibujaron en los discursos coloniales creados en España sobre Marruecos, en el periodo de las guerras coloniales del Rif entre 1909 y 1927. Estudiaremos, desde una perspectiva de género, cómo desde algunos sectores que promocionaban la colonización se quiso reivindicar que España era una nación plenamente europea, que formaba parte del mundo del progreso y la modernidad, en un periodo en que esta adscripción estaba en duda.

El colonialismo era una empresa militar, económica y política, pero también cultural $^{3}$. El mundo colonial implicaba una cosmovisión común a los diferentes países europeos. En la construcción de la jerarquía entre naciones colonizadoras y colonizadas se definía, de forma cambiante e inestable, el concepto mismo de civilización y el significado de nociones como progreso, decadencia o modernidad ${ }^{4}$. Esta cultura imperial se convirtió en un elemento esencial de la cultura europea. Apelaba tanto a las naciones con extensos imperios territoriales como a aquellas que participaron en la empresa colonial en menor medida, e incluso a las que no participaron en ella. En aquel periodo ningún europeo podía vivir al margen de esta realidad cultural ${ }^{5}$.

Esta dimensión colonial fue también fundamental en la construcción de las identidades nacionales. Estudios recientes, agrupados en el ámbito anglosajón bajo la rúbrica de "nueva historia imperial", han insistido en visibilizar las interdependencias entre colonia y metrópoli en diferentes aspectos -la definición de los límites de ciudadanía, el derecho a voto de las mujeres-, siendo la definición de la identidad nacional metropolitana uno de ellos. En un contexto europeo de imperialismo creciente, la posesión de un imperio era un atributo fundamental de la nación, no una mera característica accidental $^{6}$. Los imaginarios imperiales incluían una autorepresentación de la identidad nacional, como parte de la definición de la propia "comunidad imaginada"7. Las identidades nacionales se construían también, por tanto, en relación a los conceptos de civilización, modernidad o progreso, que se fraguaron en el marco de los imaginarios coloniales. La posición que cada nación ocupaba en la jerarquía civilización-barbarie era un elemento fundamental en la definición de su identidad ${ }^{8}$.

Saïd, Edward: Orientalisme, Vic, Eumo. 1991.

4 Cooper, Frederick; Stoler, Ann Laura: Tensions of Empire. Colonial Cultures in a Bourgeois World, Berkeley University Press, Berkeley, 1997.

5 Eley, Geoff: "Imperial Imaginary, Colonial Effect: Writing the Colony and the Metropole Together", en Catherine Hall y Keith McClelland (eds.): Race, Nation and Empire: Making Histories, 1750 to the Present, Manchester, Manchester University Press, 2010, p. 227.

6 Blanco, Alda: Cultura y conciencia imperial en la España del siglo XIX, València, Publicacions de la Universitat de València, 2012

7 Archilés, Ferran: “ ¿Ni imperio ni imperialismo? El imaginario nacional español y el imperialismo africanista en la España de la Restauración (c.1880-1909) “, en Ferran Archilés, Marta García e Ismael Saz: Nación y nacionalización. Una perspectiva comparada, València, Publicacions de la Universitat de València, 2013, p. 205.

8 Sinha, Mrinali: "Nations in an Imperial Crucible", en Philippa Levine (ed.): Gender and Empire, Oxford, Oxford University Press, 2004; Hall, Catherine y Rose, Sonya: At Home with the Empire: Metropolitan Culture 
En la línea de los planteamientos enmarcados en la historia cultural, concebimos la nación como una forma de identidad fluida, cambiante, que no debe ser entendida como una entidad fija y acabada, sino que se construye a través de su discusión y continua redefinición ${ }^{9}$. Consideramos el proyecto del colonialismo español en Marruecos como uno de los muchos escenarios donde se llevó a cabo esta discusión ${ }^{10}$.

El colonialismo español en Marruecos se caracterizó, desde el primer momento, por una cierta inestabilidad identitaria, debido a una fuerte percepción de crisis, agudizada por la derrota del 98. España se estaba hundiendo como imperio colonial en América, dirigió entonces su atención al continente africano como una forma de colonialismo compensatorio. Intentaba con ello contrarrestar una angustiosa posición de debilidad respecto al resto de potencias europeas y evitar la decadencia nacional, en el marco de un proyecto regeneracionista que se vinculaba a este nuevo imperialismo ${ }^{11}$.

El cambio de siglo estuvo marcado por esta sensación de crisis que se observaba también en otras naciones europeas como Francia y Gran Bretaña. Sus élites intelectuales sintieron esta misma preocupación por quedar relegadas en un mundo de competencia entre naciones por el control de las colonias ${ }^{12}$. Este miedo dominaba también el imaginario de las élites españolas.

El reparto colonial en el norte de África evidenció la fragilidad de la posición española en el concierto internacional, que tenía su origen en el 98. Su debilidad como potencia colonial, fue instrumentalizada por Gran Bretaña para controlar el expansionismo francés: no permitiría que Francia controlara el Estrecho y con ello todo el imperio marroquí1 ${ }^{13}$. Fruto de estas presiones internacionales, se asignó un protectorado a España de la zona norte de Marruecos en 1912. La resistencia rifeña fue notable y España se vio inmersa en varias guerras para cumplir con este encargo. En ellas, sufrió derrotas importantes que tuvieron un gran impacto en la opinión pública, como la del Barranco del Lobo de 1909 y la de Annual en $1921^{14}$. Muchos soldados murieron o cayeron prisioneros, la prensa relató los sucesos bélicos escabrosos con detalle: las emboscadas y las huidas desordenadas de los soldados ateridos, los largos días de sitio en los blocaos marroquíes sin agua ni comida y sin medios para enterrar a los muertos. Las imágenes de campos llenos de cadáveres y de soldados españoles mutilados aparecieron en la prensa. La guerra no terminó hasta que se realizó una acción militar conjunta franco-española contra el líder rifeño Abd-el-Krim. Estas

and the Imperial World, Cambridge, Cambridge University Press, 2006; Fradera, Josep Maria: La nación imperial (1750-1918), Barcelona, Edhasa, 2015.

9 Archilés, Ferran: “¿Quién necesita la nación débil? La débil nacionalización española y los historiadores”, en Alberto Sabio (et alii) (coord.): Usos de la historia y políticas de la memoria, Zaragoza, Prensas Universitarias de Zaragoza, 2004, pp. 187-208 e idem.: "Vivir la comunidad imaginada. Nacionalismo español e identidades en la España de la Restauración”, Historia de la educación. Revista interuniversitaria, 27 (2008), pp. 57-85.

10 Como ha afirmado Archilés, en el caso del colonialismo español en Marruecos no se ha explorado suficientemente esta dimensión colonial de la identidad nacional. Véase: Archilés, Ferran: “¿Ni imperio ni... " e idem.: "Piel moruna, piel imperial. Imperialismo, nación y género en la España de la Restauración (c. 1880-c. 1909) “, Mélanges de la Casa de Velázquez, 42(2) (2012), pp. 37-54.

11 Archilés, Ferran: "Ni imperio ni...., idem.: "Piel Moruna...".

12 Archilés, Ferran: "Ni imperio ni....", idem.: "Piel Moruna...".

13 Balfour, Sebastian: “España, Marruecos y las grandes potencias, 1898-1914”, en Guadalupe Gómez-Ferrer y Raquel Sánchez (eds.): Modernizar España: proyectos de reforma y apertura internacional (1898-1914), Madrid, Biblioteca Nueva, 2007.

14 Almuiña, Celso: "El impacto de Annual (1921) y la información gráfica”, en Alejandro Díez Torre (ed.): Ciencia y memoria de África, Madrid, Universidad de Alcalá de Henares, Ateneo de Madrid, 2002, pp. 403-416; La Porte, Pablo: "La respuesta urbana ante la crisis de Annual (1921-1923) “, Estudios Africanos. Revista de la Asociación Española de Africanistas, 18-19 (1996), pp. 109-124. 
guerras supusieron enormes dispendios económicos para España y fueron una fuente constante de inestabilidad política. La cuestión marroquí contribuyó decisivamente a la crisis del régimen de la Restauración ${ }^{15}$.

Aun así, los partidos dinásticos entendieron que conservar la presencia en Marruecos era fundamental para defender el papel internacional de España. No participar en esta empresa podría suponer la desaparición de España misma, que podía caer en manos de naciones más poderosas como Francia. Como afirmaba el africanista Ruiz Albéniz, el día que Marruecos fuera francés o inglés, las naciones poderosas querrían conquistar también a otros pueblos rezagados "y ahí están nuestras Canarias y Baleares, siempre sufriendo la mirada codiciosa de los extraños" ${ }^{16}$. La necesidad de participar, como el resto de potencias europeas, en la obra de la civilización era acuciante: "no podemos mostrar debilidad alguna. Hemos de cumplir los compromisos adquiridos ante las otras naciones [...] no podemos dejar que Francia ocupe nuestra parte del Rif"17.

Esta angustia que sentían muchos impulsores del colonialismo no respondía solamente al rol de España en el marco internacional a nivel político, económico o militar, o a las duras derrotas que España estaba sufriendo en Marruecos, sino que expresaba también una preocupación por la identidad nacional. Esta se debe relacionar con el proceso de orientalización de España que se produjo desde mediados del siglo XIX y se agudizó con la crisis del 98. En el discurso del romanticismo, España aparecía como un país más cercano a lo oriental que a lo europeo, África empezaba en los Pirineos ${ }^{18}$. En este proceso de estereotipación, España empezó a ser interpretada desde su pasado musulmán y así adquirió todas las supuestas características orientales: arcaísmo social, despotismo oriental. La pereza e indolencia caracterizaban a sus habitantes, dominados además por la sensualidad y pasiones excesivas ${ }^{19}$. En esta misma línea, a medida que se extendía el uso político de la idea de raza, se empezó a cuestionar que los españoles fueran realmente europeos, debido a la mezcla racial con los árabes que se había producido en la península ${ }^{20}$. A ello, debemos sumar la teoría que proclamaba la decadencia de las naciones latinas, fundamentada en un neodarwinismo pretendidamente científico. Moribundas y degeneradas, estas naciones eran incapaces de adaptarse al mundo moderno frente a la pujanza de las anglosajonas y germanas. España, especialmente a raíz del 98, se convirtió en el ejemplo más claro de esta decadencia. En una concepción que entendía que el proceso evolutivo afectaba también al desarrollo de las naciones, España había quedado anclada en un estadio anterior cercano al mundo africano ${ }^{21}$. Por tanto, su pertenencia al mundo de las naciones civilizadas caracterizadas por la ciencia, el progreso, el

15 Balfour, Sebastian: "España, Marruecos..."; La Porte, Pablo: "Marruecos y la crisis de la Restauración (19171923)", Ayer, 63 (2006), pp. 51-74.

16 Ruiz Albéniz, Víctor: Ecce homo: prueba documental y aportes inéditos sobre las causas del derrumbamiento y consecuencias de él, Madrid, Biblioteca Nueva, 1922, p. 304.

17 Bastos Ansart, Francisco: El desastre de Annual: Melilla en julio de 1921, Barcelona, Minerva, 1921, p. 257.

18 Andreu Miralles, Xavier: "El triunfo de Al-Andalus: las fronteras de Europa y la '(semi)orientalización' de España en el siglo XIX”, Saitabi: Revista de la Facultat de Geografia i Història, 55 (2005), pp. 195-210.

19 Andreu Miralles, Xavier: "La mirada de Carmen: el mite oriental d'Espanya i la identitat nacional", Afers: Fulls de recerca i pensament, 48 (2004), pp. 347-367.

20 Andreu Miralles, Xavier : "La mirada de...", e idem.: "El triunfo de...".

21 Aresti, Nerea : “A la nación por la masculinidad. Una mirada de género a la crisis del 98”, en Mary Nash (ed.): Feminidades y Masculinidades. Arquetipos y prácticas de género, Madrid, Alianza Editorial, 2014, p. 49 y siguientes. 
pensamiento racional, el orden social, el trabajo, la moralidad quedaba claramente en entredicho.

Esta estigmatización del país desde el exterior afectó también a las relaciones de género. La imagen metonímica de esta España fue la de Carmen, mujer libre, fanática y supersticiosa, y sobre todo voluptuosa y promiscua. La masculinidad nacional también fue cuestionada. En el marco de la crisis del 98, la prensa extranjera describía al español como un hombre pasional, irracional, incapaz de controlar sus instintos, con un gusto impulsivo por el uso de la fuerza bruta, ignorante y poco amigo del trabajo. Un hombre anclado en el pasado, en los tiempos gloriosos del imperio español. Aparecía como un caballero trasnochado, orgulloso y soberbio que mantenía una concepción caduca del honor ${ }^{22}$. El español estaba dominado por las pasiones amorosas y los celos que le impedían llevar una vida de trabajo y decoro. La imagen del torero o del bandolero cruel y temerario se convertían también en el estereotipo de España. Todas estas características se oponían al modelo de hombre europeo, particularmente el anglosajón, trabajador, racional y contenido, capaz de domar sus pasiones y buen marido apegado al hogar ${ }^{23}$.

La angustia por la posición de España como nación en la jerarquía civilizaciónbarbarie, progreso-decadencia debe relacionarse por tanto con su situación de subalternidad internacional, política, económica, con las derrotas coloniales en el Rif, pero también con estos discursos peyorativos sobre la identidad nacional que sentenciaban la decadencia de España. Cuando empezó a implantarse el colonialismo efectivo en Marruecos, a principios del siglo XX, sus promotores tuvieron que dialogar con esta imagen de la nación. No sabemos cómo fueron recibidos estos discursos en el común de la sociedad española, pero es cierto que algunos intelectuales intentaron negociar esta identidad asignada. Algunos la asumieron como cierta, otros reaccionaron con críticas a lo extranjero en defensa del honor nacional. Uno de los lugares en los que se produjo esta negociación fue el contexto marroquí. La empresa colonial, el gran proyecto civilizador, situaba en primer plano esta discusión sobre la identidad civilizada de España. En las páginas que siguen analizaremos cómo este proceso de redefinición y discusión identitaria se expresó a través de la categoría de género y especialmente de la masculinidad.

El discurso colonial no fue en absoluto homogéneo. En el contexto marroquí convivieron diferentes sectores ideológicos que tuvieron respuestas diversas a esta angustia nacional y concepciones divergentes de lo que debía ser la colonización española. Durante el periodo de las guerras del Rif se consolidó en Marruecos una generación de militares de tendencia particularmente conservadora. Aunque diversos ideológicamente (fascistas, monárquicos o partidarios de la república autoritaria), las experiencias compartidas en la guerra del Rif los convirtieron en un grupo cohesionado. Serán los militares que posteriormente llevarán a cabo el golpe de Estado. Estos sectores concebían la colonización como la recuperación de las glorias imperiales de España. Su referente era la vieja Castilla, austera y conquistadora. Su concepto de colonización enfatizaba, sobre todo en periodos de guerra, elementos como la victoria, la humillación del enemigo, la exaltación del honor y orgullo nacional

2 Aresti, Nerea: "A la nación por...". 
por encima de un proyecto colonizador de carácter civilizador ${ }^{24}$. Estos militares se consideraban la única parte vital de la nación, capaz de salvar a una España en crisis, frente a unos gobiernos metropolitanos débiles y materialistas. El proyecto colonial era una forma de recuperar la fortaleza nacional, un proyecto de regeneración nacional autoritaria, que implicaba la recuperación de la naturaleza imperial de España ${ }^{25}$.

Otros sectores respondieron a esta preocupación por la posición de España como nación colonial de forma distinta. Algunos socialistas, algunos sectores liberales, republicanos, e incluso conservadores que también apoyarían posteriormente el golpe de Estado, criticaron esta concepción excesivamente militarista e imperial que representaban los sectores más reaccionarios del ejército. Aunque desde posturas ideológicas diversas, la preocupación por insertarse en el grupo de las naciones civilizadas fue compartida ${ }^{26}$. Este modelo de conquista agresivo se consideraba impropio de una nación moderna y de progreso.

Estas preocupaciones no fueron exclusivas de este periodo. En los inicios de la expansión española en Marruecos, durante la Guerra de África, se produjeron debates similares, que caracterizan el pensamiento africanista Español. Por un lado la guerra se entendió como una demostración de que España no había perdido su antigua fortaleza como potencia conquistadora, después de las derrotas en América de 1824 y que no era en comparación con otras naciones europeas ni débil ni decrépita. Esta retórica apelaba también a viejos discursos sobre la conquista del infiel. Esta concepción convivía, ya en ese periodo, con un emergente discurso de la modernidad que asumía el tropo de la misión civilizadora y entendía el proyecto marroquí como una vía para la modernización de España. El regeneracionismo de finales del XIX se ligará especialmente a esta tarea colonial modernizadora ${ }^{27}$.

Estas controversias se reavivaron en este periodo y aparecieron en el debate público sobre el llamado ,problema marroquí“ que surgió en la sociedad española, especialmente después de las derrotas de 1909 y particularmente la de 1921. Destacados cronistas e impulsores del proyecto colonial escribieron obras divulgativas que pretendían concienciar a la sociedad española sobre la importancia para España de la colonización en Marruecos. Al tiempo denunciaban el rumbo equivocado que estaba tomando y reivindicaban la necesidad imperiosa de un colonialismo civilizador. Algunos de estos autores se alinearon con los militares que se sublevaron contra la República. Ello no impidió que durante el periodo colonial defendieran, a diferencia de estos sectores más agresivos, un modelo colonial de tutela y no de conquista. Es el caso del médico militar Víctor Ruiz Albéniz, quien sirvió en Marruecos siendo

24 En periodos posteriores, una vez lograda la conquista, este enfoque virará hacia posturas más civilistas. Véase: Jesen, Geoffrey: "Military Memories, and the Myth of Hispano-Arabic Identity in the Spanish Civil War", en Aurora Morcillo (ed.): Memory and Cultural History of the Spanish Civil War. Realms of Oblivion, Brill, Leiden, Boston, 2014, pp. 495-533.

25 Macías, Daniel: "El africanismo del ejército franquista", en Fernando Puell de la Villa y Sonia Alda (coords.): Fuerzas armadas y políticas de defensa durante el franquismo, Madrid, Instituto Universitario General Gutiérrez Mellado, 2010, pp. 123-146; Vizcarri, Dionisio: Nacionalismo autoritario y Orientalismo...

26 Marin, Manuela: Testigos coloniales, Barcelona, Bellaterra, 2015, p. 27.

27 Fradera, Josep Maria: La nación imperial...; Álvarez Junco, José: "La nación en duda", en Juan Luis PanMontojo (coord.): Más se perdió en Cuba, Madrid, Alianza Editorial, 1998, pp. 405-476; Blanco, Alda: Cultura y conciencia...; Archilés, Ferran: "Piel Moruna..."; Bachoud, André: Los españoles ante las campañas de Marruecos, Madrid, Espasa Calpe, 1988; Martín Corrales, Eloy: Marruecos y el colonialismo español (18591912), Barcelona, Edicions Bellaterra, 2002; Álvarez Junco, José: “La guerra como mito movilizador", en Manuel Pérez Ledesma y Rafael Cruz: Cultura y movilización en la España contemporánea, Madrid, Alianza Editorial, 1997. 
también un cronista destacado de los sucesos marroquíes (y posteriormente también de las "gestas" de los militares sublevados). O del ingeniero militar, Bastos Ansart, que fue diputado a las Cortes por el regionalismo aragonés, y posteriormente tuvo diversos cargos relacionados con la movilización militar y la propaganda franquista ${ }^{28}$. En una misma línea se expresó el escritor Giménez Caballero, que aunque defendió posteriormente posiciones ultranacionalista y autoritarias, compartía esta crítica a una acción colonial en Marruecos caduca y deficiente en comparación con Europa ${ }^{29}$.

Desde otros sectores ideológicos se reflexionó también sobre la colonización española en una misma línea discursiva. Un ejemplo de ello es la obra de Eugenio Noel, periodista, republicano y socialista que se alistó para servir en Marruecos en 1909. Criticó duramente la colonización española ineficaz y corrupta. Noel consideraba que el proyecto colonial debía servir para la modernización de España, una oportunidad que se estaba desperdiciando. La defensa de una España que debía ser civilizadora y no conquistadora la encontramos también en otros divulgadores de la realidad marroquí como el primer teniente de infantería de las Tropas de Policía Indígena de Melilla Cayetano Vázquez Sastre, quien escribió En tierras del Rif: pequeño estudio psicológico de la raza mora $(1913)^{30}$. Un ensayo que quería dar a conocer la sociedad marroquí y la colonización española. En la misma línea se encuentra la obra divulgativa del comandante de intendencia Alberto Camba que promulgaba la atracción pacífica y el hermanamiento con el pueblo marroquí o el manual para la instrucción de los soldados Para el oficial de policía indígena (1920), ${ }^{31}$ escrito por el comandante de infantería Anatolio Fuentes García, segundo jefe de la mehala jalifiana. La obra, destinada a la educación del oficial colonial, tomaba como modelo el colonialismo francés. El mismo interés nacional mostró el escritor y periodista Isaac Muñoz. De talante liberal, fue corresponsal de El Heraldo de Madrid y Nuevo Mun$d o$. Escribió una extensa obra literaria de carácter orientalista, pero también político, sobre Marruecos. Muñoz consideraba fundamental el colonialismo civilizador en Marruecos para la recuperación de la "vitalidad" de la nación ${ }^{32}$. Parte de la prensa se hizo eco también de estas reflexiones y críticas, como el periódico Nuestro tiempo, las publicaciones marroquíes África Española y El telegrama del Rif o el diario La Libertad a través, entre otros, de los artículos de su director, el periodista liberal Luis de Oteyza. Las novelas de temática marroquí adquirieron cierta popularidad en este periodo. Algunas de ellas también destilaban estas mismas ideas. Todos estos textos compartieron un mismo interés: el progreso y la pujanza de la nación, considerando el proyecto colonial fundamental para ello y compartiendo una misma actitud crítica sobre cómo este proyecto se estaba desarrollando.

Como podemos comprobar, las dicotomías civilización-barbarie, progreso-decadencia fueron asumidas de forma transversal por parte de diferentes sectores ideológicos como un eje fundamental en la reflexión sobre la identidad nacional. A continuación analizaremos cómo parte de los sectores que promovían la colonización

28 Nerín, Gustau: La guerra que vino de Africa, Barcelona, Crítica, 2005.

29 Vizcarri, Dionisio: Nacionalismo autoritario y orientalismo: la narrativa prefascista de la guerra de Marruecos (1921-1927), Bologna, Il capitello del Sole, 2004.

30 Vázquez Sastre, Cayetano: En tierras del Rif: pequeño estudio psicológico de la raza mora, Melilla, Imprenta La Africana, 1913.

31 Fuentes, Anatolio: Para el oficial de policia indigena, Tetuán, La Papelera Africana, 1920.

32 Correa, Ameliana: Bajo el signo de la alteridad: el escritor orientalista Isaac Muñoz, Alicante, Biblioteca Virtual Miguel de Cervantes, 1913. 
española en Marruecos quisieron reivindicar una España moderna y de progreso que cumpliera adecuadamente con su misión de tutela colonial ${ }^{33}$. Al mismo tiempo respondían a los discursos que presentaban España como una nación semiafricana y decadente. Esta negociación identitaria fue compleja. En primer lugar, implicó la asunción de estos discursos y por tanto la crítica a esta España agresiva y caduca. En segundo lugar, también significó una reacción: reivindicaron que España podría ser también moderna y civilizada y articularon una propuesta de rectificación. Describieron así cómo debería ser la nueva España colonial.

La historiografía reciente ha discutido las características específicas del colonialismo español en este aspecto particular. Algunos autores lo han considerado excepcional. España no se situaba respecto a Marruecos en una posición de clara superioridad civilizadora como el resto de potencias coloniales. Según su interpretación, el movimiento africanista consideraba que España y Marruecos tenían muchas similitudes: una posición de debilidad internacional semejante, la corrupción y la deficiencia administrativa eran males compartidos. El proyecto modernizador era el mismo para los dos países. Por todo ello afirma Martínez que la concepción africanista sobre la colonización "descansaba más en el ejemplo del programa regeneracionista español que en los discursos de franca superioridad de tipo colonialista o civilizador"34.

Otras autoras como Martín Márquez han argumentado esta misma excepcionalidad por motivos culturales. Ella sostiene que se puede leer, de forma implícita en algunas producciones culturales coloniales, una cierta hibridación entre la identidad española y africana. Debido al pasado musulmán en la península y a la supuesta cercanía racial ibero-bereber, una parte de las elites coloniales consideró que España era un país próximo cultural y socialmente a Marruecos, y debido a ello no adoptó una postura jerárquica ni de superioridad racial tan clara como otras naciones europeas ${ }^{35}$. Por tanto, estos autores entenderían que el proyecto colonial de España no puede compararse con el de otros países y no representa un proyecto netamente civilizador, lo cual situaría la construcción de la identidad nacional española en una posición ambigua respecto a las ideas de progreso, modernidad y civilización. Otros análisis han afirmado, en cambio, que los españoles en Marruecos estaban tan convencidos de representar la civilización occidental como cualquier otro país europeo ${ }^{36}$.

33 Estos críticos se diferencian de los sectores sociales que fueron contrarios al proyecto colonial. Lo consideraban injusto, solo beneficiaba a las elites y forzaba a los hombres de las clases populares a servir como soldados en Marruecos. Desde el socialismo, el anarquismo o el catalanismo apostaron por el abandonismo, dejar Marruecos. Véase a modo de ejemplo: Barea, Arturo: La forja de un rebelde II. La ruta, Biblioteca El Mundo, Madrid, 2001 (1 $1^{\mathrm{a}}$ ed. 1943); Sender, Ramon: Imán, Ediciones Destino, Barcelona, 2003 (1 ${ }^{\mathrm{a}}$ ed. 1930) o Prous i Vila, Josep Maria: Quatre gotes de sang. Dietari d'un català al Marroc, Reus, Edicions del Centre de Lectura-Prous Science, 2003 ( $1^{\text {a }}$ ed. 1934).

34 Martínez Antonio, Francisco Javier: "Regeneracionismo, sanidad y discurso racial: Felipe Ovilo Canales y la confluencia entre España y Marruecos a finales del siglo XIX", Dynamis: Acta Hispanica ad Medicinae Scientiarumque Historiam Illustrandam, 29 (2009), p. 31. Véase también: Martínez, Franciso Javier y González, Irene (ed.): Regenerar España y Marruecos. Ciencia y educación en las relaciones hispano-marroquies a finales del siglo XIX, Madrid, Consejo Superior de Investigaciones Científicas, 2011.

35 Martín Márquez, Susan: Desorientaciones. El colonialismo español en África y la performance de identidad, Barcelona, Edicions Bellaterra, 2012. Marín analiza también de forma exhaustiva las interacciones y los lugares de proximidad e intercambio entre españoles y marroquies en la esfera colonial. Entiende sin embargo que la posición mayoritaria en el discurso colonial fue la identificación de España con la superioridad europea. Véase Marín, Manuela: Testigos coloniales..., p. 27.

36 Archilés, Ferran: "Ni imperio ni...", p. 218; Mateo Dieste, Josep Lluis: "El moro" entre los primitivos. El caso del protectorado español en Marruecos, Barcelona, Fundació "La Caixa”, 1997; Martín Corrales, Eloy: 
En el presente trabajo analizaremos precisamente este aspecto: la importancia que tuvieron en el marco del discurso colonial las dicotomías civilización-barbarie, progreso-atraso, en la construcción de la identidad nacional española. Realizaremos este análisis a través de un aspecto muy significativo en la construcción de identidades: los arquetipos de género, especialmente la masculinidad. Con ello podremos valorar también si el caso español fue excepcional en comparación con otros países coloniales.

La importancia de relacionar el género con la nación -y también otros vectores identitarios, como la clase o la raza- se ha puesto de relieve desde la historia y los estudios de género y culturales ${ }^{37}$. Esta relación intrínseca es fundamental en el análisis de los arquetipos de género normativos en cada contexto pero también en el estudio de la construcción de identidades nacionales. En este sentido se ha descrito "la capacidad significante y ordenadora del dualismo sexual", que se ha "manifestado útil también en la creación de discursos y símbolos patrióticos"38. La nación se representa simbólicamente, se hace tangible, se encarna en imágenes de género. Esta capacidad del género para representar la nación se ha analizado sobre todo a través de la feminidad ${ }^{39}$. En el presente trabajo nos centraremos en cambio en la masculinidad, ya que consideramos que en nuestro contexto esta discusión sobre la identidad nacional se llevó a cabo a través de los arquetipos, los valores y el cuerpo masculinos. Esta reflexión nacional se expresó a través de una figura concreta: el hombre colonizador español. Diferentes conceptos de lo que debía ser esta virilidad colonial se discutieron durante las guerras del Rif. Estos modelos representaron diferentes concepciones de la identidad de España como nación colonial.

\section{El conquistador español}

La hombría española estuvo en el centro de las críticas que se vertieron sobre la actuación colonial en Marruecos, después de las derrotas de 1909 y, especialmente, de 1921. Un nombre fue protagonista, el del general Silvestre. Fue él quien condujo las operaciones que terminaron en el desastre de Annual y el que, al verse vencido, decidió suicidarse. Esta figura masculina se convirtió en la imagen icónica del conquistador español impetuoso y bravucón que representaba todas las características nefastas de la acción colonial española: la de una nación excesivamente agresiva que no pretendía civilizar sino meramente conquistar. Este modelo de hombre fue

"Marruecos y los marroquíes en la propaganda oficial del protectorado", Mélanges de la Casa de Velázquez, 37 (2007), pp. 83-108.

37 Scott, Joan: "Gender: a Useful Category of Historical Analysis”, American History Review, 91 (1986), pp. 10531075; McClintock, Anne: Imperial Leather: Race, Gender, and Sexuality in the Colonial Contest, New York, Routledge, 1995; Sinha, Mrinali: "Nations in...".

38 Aresti, Nerea: “A la nación por...,", p. 1.

39 Se ha descrito cómo la nación se presenta a través de imágenes femeninas o cómo la doncella violada o amenazada es la metáfora del territorio nacional en peligro en contextos de guerra. Como esposas y madres, transmisoras biológicas y culturales de la tradición, las mujeres se convierten en la esencia de la nación, su núcleo definitorio. Véase: Blom, Ida, Hagemann, Karen y Hall, Catherine: Gendered Nations, Nationalism and Gender Order in Long Nineteenth Century, Oxford, New York, Berg, 2000; Joly, Maud: "Souffrances des corps, souffrances des territoires: la République espagnole en guerre se raconte", Mélanges de la Casa de Velázquez, 42 (2), (2012), pp. 73-90 y Yuval Davis, Nira: Gender and nation, London, Sage Publications, 1997. En el contexto colonial también se ha analizado preferentemente cómo la sociedad colonizada y su atraso y falta de civilización se representa a través de la feminidad. Véase Marín, Manuela: Testigos coloniales..., p. 257-275. 
censurado, en primer lugar, por su impulsividad, por su ansia de batalla. Cuando se acercaban las operaciones vivía "devorado por la impaciencia" ${ }^{40}$. Ya desde niño, Silvestre era de "fácil de entusiasmo", un hombre "vehemente" con un carácter basado en la acción y la lucha ${ }^{41}$. Se criticó duramente esta tendencia de los españoles a ser poco previsores y su gusto infantil e instintivo por el uso de la fuerza. Igual que en los generales, en los soldados se inculcaba este deseo alocado de participar en las acciones más peligrosas. Los soldados tendían a "excederse en el cumplimiento del deber, y a superarse a sí mismos, incluso portándose como titanes los que para serlo no nacieron" 42 .

La principal característica masculina del español conquistador era, pues, una forma de valor temerario, el arrojo, la acometividad. Este valor irreflexivo aparecía como algo instintivo e irracional. Se trataba de una capacidad viril para asumir riesgos a pesar del peligro cierto. Esta cualidad se definía como "bravura" y era el atributo masculino que garantizaba la victoria. El general Silvestre no se detenía a reflexionar serenamente sobre la táctica más adecuada, no prestaba atención a los cautos y a los políticos, simplemente se dejaba llevar por sus impulsos bravos, las operaciones se ganaban "por redaños" 43 . Según el relato de Oteyza, los rifeños intentaron pactar y evitar la guerra pero Silvestre consideraba que "España tenía poder para ir donde le diera la gana [...] prefería llegar por la fuerza, mejor que templando gaitas" $"$. En este sentido, se oponía en la prensa el conquistador español arrojado al jefe rifeño, Abd-el-Krim, un hombre con una actitud "templada y austera", sensato, quiso negociar, en cambio desde la oficialidad española "por bravuconería se le desdeñó" 45 . Los Rifeños deseaban la paz y esperaban de España progreso y civilización, en cambio recibieron "arbitrariedades, abusos y atropellos"46.

Esta cualidad masculina del valor irreflexivo se puede interpretar como emocional y en cierto modo también como corporal. Esta era otra de las características que afeaba el modelo de hombre conquistador, su énfasis en el vigor corporal y emocional en contraposición al cálculo y a la serenidad racional. En la prensa, se criticaba este aspecto al afirmar que

se da el caso paradójico de que, intelectualmente, Abd-el-Krim, el jefe de los moros, fuese superior a nuestro comandante general, cuyo fuerte, como sabe todo el mundo, residía en otro órgano, que no es, precisamente, el cerebro ${ }^{47}$.

Para mostrar lo ridículo de esta preponderancia de lo corporal, Ruiz Albéniz relataba una escena en que Silvestre se presentaba ante los rifeños del siguiente modo:

Yo soy un hombre valiente. He estado en Cuba, y he luchado siempre bravamente. Yo tengo en mi cuerpo todas estas heridas (y se desabrochó la guerrera, y mostró también su mano mutilada). Aquel monte -y por una ventana señaló a Quilates...

\footnotetext{
40 Ruiz Albéniz, Víctor: Ecce homo..., p. 210.

41 Bastos Ansart, Francisco: El desastre de..., p. 93.

42 Ruiz Albéniz, Víctor: Ecce homo..., p. 8.

43 Ruiz Albéniz, Víctor: Ecce homo..., p. 210.

44 Oteyza, Luis: Abd-el-Krim y los prisioneros, Melilla, Ciudad Autónoma de Melilla, 2000 [1922], p. 91.

45 Guixé, Juan: "El jefe de la harca enemiga, Abd-el-Krim”, El Heraldo de Madrid, 4 de agosto de 1921, p. 1.

46 Oteyza, Luis: Abd-el-Krim..., p. 90.

47 Guixé, Juan: "El jefe de la harca....", p. 1.
} 
lo tomo yo con mi... (hizo alusión a un atributo de virilidad). Los moros callaron avergonzados [...], no comprendían a tenor de qué el general se dejaba ir por el camino de las bravatas ${ }^{48}$.

Esta forma impetuosa de hacer la guerra resultaba altamente ineficaz, producía víctimas innecesarias y conducía a derrotas que con mayor previsión habrían sido evitadas. En el diagnóstico de la novela popular escrita por el periodista Tomás Royo, Allá en el Rif, la guerra era el resultado de una malentendida masculinidad

provocada, por quienes suponen erróneamente, que se es más fuerte cuánto más rudeza hay en todos los actos, que confuden también la tozudez con la voluntad y que creen, que la astucia, la movilidad de espíritu es debilidad [...] da pena ${ }^{49}$.

Estos defectos se relacionaban también con un orgullo mal entendido basado en la popularidad y el ansia de reconocimiento. En los soldados "cabía siempre la posibilidad de sobresalir, de destacarse, de alcanzar la santa aureola del triunfo o del sacrificio" $" 50$. Este modelo se contraponía a lo que se definía como el hombre colonizador moderno, es decir, mesurado y reflexivo. Ruiz Albéniz se preguntaba: “¿Á que vienen las impaciencias? ¿Por qué no obrar con prudencia, descansadamente, sin provocar el derroche de sangre con insensatas gallardías belicosas? [...] está en nuestras manos, en nuestros cerebros de hombre civilizados el hacerlo" 51.

Otra crítica que se hacía al conquistador español estaba relacionada con su autoritarismo desmesurado. Los generales españoles se imponían a la tropa por la fuerza y no por sus virtudes: "sólo el palo, el miedo y el castigo era efectivo en aquella masa" ${ }^{2}$. Se trataba de un autoritarismo que resultaba incluso grotesco. Así lo explicitaba Eugenio Noel: "Me molesta aquel orgullo estéril, y me entristece ese prurito de mandar por mandar" 53 . La incultura y la falta de conocimiento de las técnicas militares más avanzadas eran también defectos del conquistador español: "El oficial que crea que el soldado ha de ser una bestia de carga ó un héroe probable, ignora en absoluto la táctica moderna" 54 . La modernidad requería soldados instruidos y preparados, no héroes. Los españoles en cambio "lo encomiendan todo á la punta de la bayoneta [cuando en la actualidad los asuntos más graves] dulzura y paz reclaman" ${ }^{55}$. Estos oficiales aparecían además como hombres incultos e ignorantes. Noel observaba en ellos "muy pocos rasgos de inteligencia; todo es mohoso, de segunda mano, parabólico. Un duque alardea de ingenio, juega a vocablos torpes y repugna oírle" ${ }^{56}$. En la descripción de Giménez Caballero, la oficialidad española aparecía incapaz de una organización moderna y eficiente "sobre el común denominador de la negligencia, del cansancio, marcha todo lo nuestro" $" 57$. Según estas críticas este defecto de los

48 Ruiz Albéniz, Víctor: Ecce homo..., p. 240.

49 Royo, Tomás: Allá, en el Rif: del amor y de la guerra, Zaragoza, Imprenta Heraldo de Aragón, 1922 , p. 61.

50 Ruiz Albéniz, Víctor: Ecce homo..., p. 8.

51 Ruiz Albéniz, Víctor: La Campaña del Rif: la verdad de la guerra, Madrid, Establecimiento Tipográfico y Editorial, 1909 , p. 79.

52 Noel, Eugenio: Notas de un voluntario: guerra de Melilla, 1909, Madrid, Imp. Primitivo Fernández, 1909 , p. 68.

53 Noel, Eugenio: Notas de un..., p. 197.

54 Noel, Eugenio: Notas de un..., p. 272.

55 Noel, Eugenio: Notas de un..., p. 267.

56 Noel, Eugenio: Notas de un..., p. 214.

57 Giménez, Ernesto: Notas marruecas de un soldado, Barcelona, Planeta, 1983 [1923], p. 112. 
militares españoles fue la causa de sus derrotas: "Pero su ignorancia caro les cuesta [...] siempre improvisando energías y derrochando esfuerzos" 58 . Incluso los rifeños consideraban a los españoles ineptos e ineficaces. En las crónicas de Oteyza lo marroquíes enumeraban sus continuos errores y torpezas, el periodista concluía "no nos tienen ni respeto ni admiración"59.

Este hombre conquistador adolecía además del mínimo rigor moral. Diversos autores denunciaron la corrupción de costumbres que se producía en las ciudades marroquíes. En lugar del trabajo productivo los jefes y oficiales "se pasan jugando las noches el plus de campaña. ¡Qué estupidez! [...] ¿Qué emoción puede procurarse un espíritu de éstos, poco cultivados, de pasiones violentas y groseras? Ya que no hay otro heroísmo se dedican al juego" 60 . Melilla, era, además, lugar de "amores y amoríos"61. Muchos reclamaron la necesidad urgente de sanear las costumbres del ejército en dos aspectos principales, el juego y la prostitución. Silvestre, en cambio, "se reía de tales severidades" $"$. Todas estas críticas no se referían solamente a la oficialidad, sino también a los colonos. En las páginas de África Española se lamentaba Jevenois del "espectáculo que algunos compatriotas nuestros dan en Tetuán y que no sirve para elevar ante el indígena la superioridad de la raza"63. En comparación con el inglés que aparecía como “espléndido señor [...], pródigo en dinero y de extraordinario poder [...] ¡Qué tristeza y qué amargura, al lado de esto, cuando se mira el papel español! ¿Qué enseñamos á los marroquíes? En Tánger, golfos de playa, mujeres públicas, comercios á la altura de los suyos, desertores" 64 .

Estos relatos brindaban una imagen muy determinada del hombre conquistador español, arrojado, bravo, temerario y con un gusto excesivo por el uso de la fuerza bruta. Poseía una forma de coraje excesivamente corporal e irracional. Era autoritario, ignorante y de dudosa moralidad. Como nos hemos propuesto, debemos relacionar estas imágenes masculinas con la construcción de la identidad nacional en este contexto colonial.

Según estas críticas los vicios de este hombre conquistador se consideraban específicamente españoles. Este hombre bravucón representaba genuinamente lo español. Bastos Ansart lamentaba:

La crítica es cierta, la queja de la nación fundada. Estamos todos tan hartos de ese matonismo odioso de la disputa callejera, del valiente de café, del héroe tabernario, que, al ver a esos generales heroicos, nos acordamos del matonismo y al matonismo le odiamos. Hay, desgraciadamente, parte de verdad [...]. Hay, finalmente, una absoluta necesidad de modificación ${ }^{65}$.

58 Noel, Eugenio: Notas de un..., p. 266.

59 Oteyza, Luis: Abd-el-Krim..., p. 142 y ss.

60 Giménez, Ernesto: Notas marruecas..., p. 27.

61 Ruiz Albéniz, Víctor: Ecce homo..., p. 219.

62 Ruiz Albéniz, Víctor: Ecce homo..., p. 104.

63 s.a. "La inmigración", África española, 15 de diciembre de 1913, p. 252. César Juarros también reclama un selección precisa de los colonos en Juarros, César: "La selección de la colonia", África española, 30 de enero de 1914.

64 Jenevois, Pedro: "Nuestro ejército en África", Nuestro tiempo, Marzo de 1903, p. 418. Para una reflexión sobre la emigración de colonos españoles a Marruecos, véase Marín, Manuela: Testigos coloniales..., p. 55-61.

65 Bastos Ansart, Francisco: El desastre de..., p. 211. 
En este lamento se reproducen los discursos orientalizantes sobre los hombres españoles que hemos descrito anteriormente. El hombre violento, el bruto de taberna era el prototipo español:

Odiemos el matonismo de esa frase española 'por riñones', odiémosla siempre. Odiémosla si la pronuncia el chulo, y odiémosla y reprobémosla si la dice o piensa un general ${ }^{66}$.

Este modelo masculino tan denostado era la encarnación más explícita de toda la nación, de una España trasnochada que basaba su preeminencia en el triunfo de la fuerza y no en la razón del progreso. En comparación con otros países, que conquistaban voluntades a través de la educación y la superioridad del conocimiento y la ciencia, esta forma bruta de colonizar se consideraba antigua e incompatible con la modernidad. Ruiz Albéniz reiteraba este argumento: en el escenario marroquí dominaba el "ambiente imperialista" y "mosqueteril"67 y se olvidaba la "conquista moral" 68 . Insistía en que España no tenía ninguna vocación de compenetración con el pueblo marroquí, no conocía el significado de la palabra protectorado: "nos quisimos imponer; no nos importaba hacernos útiles, precisos, deseados como sembradores de vida. Éste es nuestro principal error y la base de nuestros infortunios en Marruecos" "69. Como ejemplo de ello, Oteyza denunciaba que en lugar de demostrar un respeto protector por la religión local, se construyó en Nador una iglesia con una imagen de Santiago Matamoros. El capitán de infantería Eladio Amigó consideraba esta actitud ramplona y anticuada, "larvas de la reconquista [...] como si el motivo de nuestra penetración en Tetuán hubiera sido por un auto de fé [sic] en lugar de una razón de Estado"70. En definitiva, todos los españoles en Marruecos, desde los generales a los ingenieros, estaban convencidos de que "estábamos en país conquistado"71. El hombre bravucón e irreflexivo representaba esta tradición española de conquista agresiva.

En estas críticas los periodistas y divulgadores interesados en la cuestión marroquí analizaban cuál era el problema colonial de España, aquel que llevaba a continuas derrotas en Marruecos y a una posición de subalternidad internacional. Como hemos comprobado, no encontraron la respuesta en elementos políticos, económicos o en las relaciones internacionales, sino en una serie de características propias de la identidad nacional, la tradición e incluso la raza española. Estos atributos de la masculinidad tan criticados eran también las nefastas características de toda la nación. Esta supuesta incapacidad para civilizar y esta tendencia a la conquista bruta eran propias de "nuestras malas costumbres políticas, nuestra ausencia de sentido práctico y el hervor imperialista que llevamos en la sangre los españoles"72. España como nación no se caracterizaba por el pragmatismo, padecía un ansia de violencia y "un vesánico

66 Bastos Ansart, Francisco: El desastre de..., p. 213.

67 Ruiz Albéniz, Víctor: Ecce homo..., p. 210.

68 Ruiz Albéniz, Víctor: Ecce homo..., p. 35.

69 Ruiz Albéniz, Víctor: Ecce homo..., p. 44.

70 Amigo, Eladio: Ideario politico militar, Tenerife, 1928, p. 178, citado en Marín, Manuela: Testigos coloniales..., p. 31.

71 Ruiz Albéniz, Víctor: Ecce homo..., p. 31.

72 Ruiz Albéniz, Víctor: Ecce homo..., p. 37. 
o inextinguible deseo de conquistas" "73. Como el general español arrojado actuaba sin reflexión ni cálculo, dominada por una especie de locura propia de la raza -la lleva incluso en la sangre- por vencer y dominar. Como el conquistador español, poseía una "atávica manía de grandezas" ". La ignorancia y la falta de previsión eran también defectos nacionales. Se denunciaba que "la tendencia muy del gusto español ha sido [...] la de resolver los trances apurados cediendo la vez a la vehemencia en vez de ir abriendo cauces a la reflexión y al cálculo"75. El amor al trabajo no era tampoco una virtud española. La raza quizá tenía cualidades aventureras, "ciertamente pasión por la lotería, por las emigraciones, en condiciones imaginarias, fabulosas pero un trabajo serio y constante, de fecunda colonización, hace retraerse al más atrevido"76. Este hombre conquistador encarnaba, por tanto, los defectos de todo un pueblo que

con llamarse noble, con ser altanero y con fiarlo todo a la Providencia, cuando no a la casualidad, cree cubiertos todos sus deberes y cumplidos a satisfacción sus fines todos. ¡Así nos va en el mundo! ${ }^{77}$.

En definitiva, un pueblo que confiaba en la fuerza, el valor, el arrojo, el ímpetu más que en el conocimiento y la racionalidad. Este diagnóstico era compartido por Eugenio Noel, que consideraba como un "vicio español" el "suplir los medios con heroísmos"78, lo cual era definido finalmente como un ridículo "infantil y suicida culto al heroísmo"79. Criticaban, por tanto, a una nación que se caracterizaba por los valores masculinos -caducos-del heroísmo y no por la cultura, la reflexión y la ciencia.

Como podemos comprobar, las características de la masculinidad tan criticadas en este discurso se relacionaban con unas cualidades nacionales, supuestamente características de la "raza" o de la "cultura" españolas. Y serían también propias de la tradición. Los diversos autores críticos con la acción colonizadora apelaban recurrentemente al referente nefasto de Cuba, que todavía marcaba la identidad de España como nación colonial. Noel consideraba la colonización en Marruecos

obra inepta, la incultura y la imprevisión acumulando error sobre error [...] Y porque vi en la guerra que éramos los mismos bárbaros que improvisaban tácticas excéntricas en los campos carlistas, cubanos y filipinos ${ }^{80}$.

Los desaciertos de las campañas marroquíes eran concebidos como un episodio más de esta desdichada tradición, que también se encarnaba en una figura masculina, Don Quijote, el hombre iluminado, iluso, fantasioso que vive de grandezas infundadas. Así describe Giménez al soldado español que llega a Marruecos “De Quijote, al fin hijo suyo, trajiste su carne macilenta y triste, y quizá también su magín erróneo y fantástico" $"$. Así era representado el varón español conquistador y con él toda la nación.

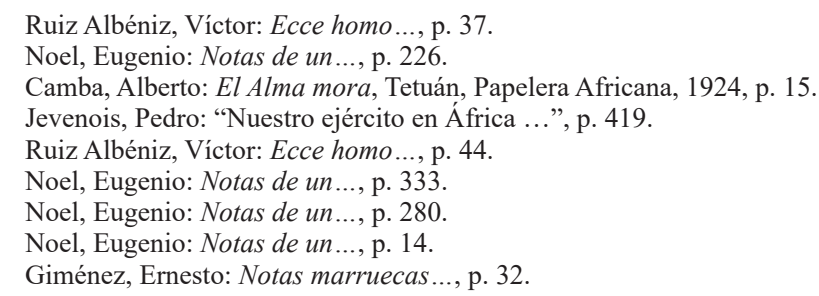


Europa era un referente constante en estos discursos y la comparación con otras naciones era habitual. Así lo expresaba Bastos Ansart:

es constante hablar de valor; esos actos heroicos incesantes [...] todo eso parece ilógico, anticuado, no se puede entender. ¿Por qué no se emplean los métodos de la Gran Guerra? ¿Cuándo, entre los alemanes, se hablaba sólo de valor? Se hablaba de un cañón nuevo ${ }^{82}$.

En otras naciones la victoria no se conseguía a través de virtudes masculinas corporales e irracionales, sino a través de la cultura y la tecnología. Confiar en determinados atributos viriles como el heroísmo vacío era propio de países atrasados, bárbaros, desde la idea de que "un ejército de héroes es un pueblo de bestias" eran, para Eugenio Noel, los fundamentos del éxito de las naciones europeas: "en Alemania, la cultura, la escuela y el libro; o, como en Suiza, el trabajo, la honradez y el fabrilismo" 84 .

Como podemos comprobar, estas críticas asumían en parte los discursos que representaban España desde el exterior en términos orientalizantes como una nación decadente y a sus hombres como bandidos exaltados. En el marco del discurso colonial se consideró efectivamente que estos defectos eran específicos de la identidad española y no afeaban a otras naciones, lo cual avergonzaba a muchos de estos escritores críticos. Giménez recorría apesadumbrado el Gibraltar bajo dominio de Inglaterra "civilización sana, llena de delicadezas y suntuosidades", observaba "la montura enfranelada del gentleman" pero [...] cuando se miraba el propio uniforme español sentía "deseo de llorar" ${ }^{85}$. Muchos lamentaban que España siguiera transmitiendo una imagen romántica hacia el exterior: "Y he aquí que al general extranjero le fue presentado un soldado gallardísimo, digno de un cromo de bandido á lo Delacroix, con máuser, guitarra y navaja" ${ }^{86}$. Profundamente preocupados por ello, creían que los generales descritos "ponen al país en ridículo, que hacen un grande mal"87. La crítica a estos supuestos defectos, asumidos como específicamente españoles, fue una de las reacciones a los discursos que calificaban a España como una nación decadente y semiafricana. En estas reflexiones sobre la colonización, otra imagen masculina fue decisiva en el diálogo con esta identidad asignada.

\section{El hombre marroquí}

En el marco del discurso colonial el modelo del conquistador español dialogaba de forma compleja con la figura del hombre marroquí. Como sabemos, desde los estudios postcoloniales, se ha resaltado la importancia del "otro/a" en la definición de la propia identidad. En este sentido, se concibe la construcción de la identidad y la diferencia como un proceso interdependiente en el que no se puede entender

\footnotetext{
Bastos Ansart, Francisco: El desastre de..., p. 211.

Noel, Eugenio: Notas de un..., p. 265.

Noel, Eugenio: Notas de un..., p. 265.

Giménez, Ernesto: Notas marruecas..., p. 181.

Noel, Eugenio: Notas de un ..., p. 268.

Bastos Ansart, Francisco: El desastre de..., p. 215.
} 
el "nosotros" sin el "otro" 88 . La imagen del hombre marroquí fue también protagonista de este discurso y decisiva en la construcción de la identidad española. Esta imagen aparecía a través de una representación orientalizante que enfatizaba los elementos exóticos en las figuras del guerrero rifeño y del aristócrata marroquí con la que los diversos autores pretendían evocar la imagen de los antiguos califas de Al-Andalus.

Los varones marroquíes descritos en estas obras poseían características viriles muy concretas. Eran hombres llenos de pulsiones interiores difícilmente controlables "en el fondo tienen un sabor y un resultado ardiente, apasionado, turbulento" 89 . Descritos como ardorosos e impulsivos "de negros ojos inquirentes, en cuyas pupilas fosforece la llamarada sensual [...] y la feroz impetuosidad de sus pasiones" La figura del jinete soberbio y orgulloso era comúnmente evocada. En su novela marroquí Raida describía a "los seguros y apuestos ginetes [sic], bizarra y gallardamente montados sobre majestuosos y fogosos potros cerreros" "91. Estas descripciones aludían a características masculinas similares a las tan criticadas en el conquistador español impetuoso.

De un modo similar a los generales españoles, los marroquíes eran descritos como hombres valientes, pero con un valor temerario: eran capaces de las acciones más arriesgadas sin tener miedo de las consecuencias, incluso de la muerte. Este coraje era también irracional e irreflexivo: "a la hora del combate el rifeño se muestra tan arrojado que llega a la temeridad y tan duro que llega a la ferocidad" 92 . Los marroquíes tenían también un gusto innato por el uso de la fuerza bruta y la violencia, "sus ilusiones e ideales los cifran en la posesión de un arma de fuego [...]. Por el barod (pólvora) sienten un verdadero entusiasmo"93.

Esta forma de valor se relacionaba, también en el caso de los marroquíes, con el cuerpo. Así era descrito el rifeño poseía "agilidad de tigre que da a las carnes del moro los músculos de la gacela, los anillos del reptil y los nervios del gato montés" y tenía "proverbiales cualidades de sobriedad y vigor"

Finalmente, la imagen del hombre marroquí representaba una masculinidad conquistadora, con ansias de dominación que evocaba la grandeza y la pujanza de la antigua civilización árabe que poseyó un gran imperio. Era recurrente que las descripciones de los marroquíes actuales evocaran figuras viriles del pasado, estaban "impregnados de una civilización quintaesenciada y arqueológica"96.

Cuando veo moros de la policía a caballo, me parecen personajes guerreros de los antiguos tiempos, tanto por sus vestimentas, como por su seriedad. Es tal su vanidad y orgullo que parece van pretendiendo infundir miedo a todo el mundo ${ }^{97}$.

88 Hall, Stuart (ed.): Representation. Cultural Representations and Signifying Practices, Londres, Sage Publications, 1997; Saïd, Edward: Orientalisme....

89 Giménez, Ernesto: Notas marruecas..., p. 17.

90 Camba, Alberto: Alma mora..., p. 16.

91 Raida, Pedro y Raida, Maximiliano: Aires Mogrebinos, Sevilla, Imp. El Mercantil Sevillano, 1908, p. 37.

92 s.a: "Lo que dice un indígena", La Vanguardia, 10 de agosto de 1921, p. 9.

93 Vázquez Sastre, Cayetano: En tierras del Rif..., p. 34.

94 Noel, Eugenio: Notas de un..., p. 47.

95 S.a: “Al pueblo español”, Telegrama del Rif, 26 de agosto de 1923, p. 3.

96 Giménez, Ernesto: Notas marruecas..., p. 17.

97 Sánchez, Juan: Diario de un soldado en la campaña de Marruecos 1921-1922, Serradilla, Imprenta de El Cronista, 1922, p. 30 . 
El paralelismo con el conquistador español y su pasado glorioso en América era evidente. En el cuerpo y las virtudes masculinas de estos hombres vivía el pasado triunfante del imperio:

diríase que desfilan siempre ante sus pupilas gigantescos fantasmas de imperio, soberbias imágenes de dominación. [...] En el esplendor máximo de su virilidad, este caudillo encarna una de las más potentes fuerzas y una de las más caballerescas tradiciones del Mogreb ${ }^{98}$.

Sin embargo, en estas descripciones el hombre marroquí aparecía igual que el conquistador español, como una figura antigua, con unas cualidades masculinas que eran útiles en el pasado pero en la actualidad resultaban inservibles y caducas:

Muley-Hafid representa la energía, la fiereza, la acometividad ágil, la tenacidad firme y el impulso dominador [...]. En este Príncipe, que recuerda á los antiguos y fabulosos califas de Oriente, la insigne sangre árabe revive con violenta pujanza, tan gallarda como inútil ${ }^{99}$.

En este discurso el hombre marroquí representaba a toda una sociedad antiguamente brillante y poderosa pero que actualmente había caído en decadencia, incompatible con la modernidad estaba sometida a la dominación extranjera. Isaac Muñoz lo expresaba representando a estos notables como hombres nostálgicos de su pasado, resignados e impotentes, con unas pulsiones viriles que ya no podían expresar:

Sus ojos son ardorosos, brillantes, llenos de pasión, de vehemencia y de tristeza oculta y tenaz [...] su boca es sutil, orgullosa y desencantada, y todo su aire es de melancolía, de resignación, de ensueño, de solitarismo, tal vez hecho con un poco de desdén y con un mucho de dolor [...] se envuelve gallardamente en un blanco 'suljam' de seda transparente ${ }^{100}$.

En este discurso, la imagen masculina del "otro", el africano, era también importante en la reflexión sobre la identidad de la España colonial. Era manifiesta la semejanza entre el hombre marroquí y el conquistador español. Ambos compartían ciertas características de la masculinidad que eran censuradas en esta retórica: impulsividad y pasiones excesivas, soberbia, arrojo irracional, autoritarismo, ansia de dominio. Del mismo modo, ambos modelos masculinos de conquistadores eran considerados caducos. Igual que en el caso del imperio árabe, los episodios gloriosos del pasado español, las gestas del caballero conquistador, ya no podían servir en la actualidad para definir la nación, eran valores antiguos, obsoletos, compartidos con el mundo oriental ahora en decadencia y desprestigiado. De esta forma, a través de la figura del hombre marroquí decadente y nostálgico de su pasado se dialogaba con la identidad africana asignada a España. La imagen masculina de este caballero africano representaba todo lo que España no debía ser: una antigualla, sin poder, con un pasado glorioso pero caída en decadencia, con cualidades poco concordantes con el mundo moderno.

\footnotetext{
98 Muñoz, Isaac: La corte de..., p. 24.

99 Muñoz, Isaac: La corte de..., p. 108.

100 Muñoz, Isaac: La corte de ..., p. 72.
} 
Ambas imágenes, la del hombre español y la del marroquí, resultaban finalmente en una crítica a una España que debía corregirse, regenerarse, abandonando su querencia por el heroísmo y el ímpetu conquistador, si no quería acabar disminuida y en manos de otras potencias más fuertes, tal y como le había sucedido al imperio marroquí. España debía alejarse de lo africano e insertarse en el mundo de las naciones modernas. Así lo expresaron los diferentes autores críticos a través de una propuesta de rectificación que se manifestaba a través de un nuevo modelo de masculinidad colonial: el padre.

\section{El colonizador español como padre}

En el proceso de negociación identitaria que implicaba este discurso, los autores analizados asumían como ciertas, en algún grado, las descripciones que definían España como decadente y oriental. Al mismo tiempo, intentaban negociar estas características atribuidas a medio camino entre la reacción defensiva ante estas categorizaciones peyorativas y la propuesta de una nueva España civilizadora. Esta se encarnaba en un nuevo hombre conquistador que se formulaba como un anhelo, casi como una reivindicación.

Isaac Muñoz quiso así reivindicar que los españoles eran y podían llegar a ser hombres civilizados. En un intento de contrarrestar las críticas francesas a los colonos españoles en Argelia, afirmó:

No son [los españoles] rufianes de Andalucía y de Calabria, como desatinadamente los llaman los franceses [...] no han dominado tenaz y profundamente en la Argelia por su crueldad, por sus rampantes instintos de presa, por su voracidad intransigente, sino por su laboriosidad silenciosa ${ }^{101}$.

La negación de estas características atribuidas quería afirmar una cualidad moderna para los españoles: el amor al trabajo. Esta negociación de la propia identidad debía, también, diferenciar el hombre español del africano.

No son los españoles del Rif, como pretenden los franceses, nuevas hordas sarracenas que se lanzan sobre el África con fieros ímpetus ancestrales; son europeos como los franceses, de la más ilustre y prócer sangre latina ${ }^{102}$.

Bastos Ansart se sumaba a esta reivindicación asociando el hombre español con el trabajo pacífico y alejándolo de lo que significaba la masculinidad marroquí guerrera:

¿Cómo comparar los cien arriesgados montaraces, bárbaros moros (bárbaros, pero con su fusil Lebel nuca se olvide) con cien buenos muchachos nuestros, acostumbrados al pacífico cultivo del campo, al telar, a la fábrica, al pastoreo? ${ }^{103}$.

101 Muñoz, Isaac: La corte de..., p. 41.

102 Muñoz, Isaac: La corte de..., p. 42.

103 Bastos Ansart, Francisco: El desastre de..., p. 216. 
El mismo Isaac Muñoz explicitaba que esta vindicación era una defensa de lo español ante las críticas externas, pero también un anhelo, un deseo de enmienda. Esto se hacía evidente cuando contraponía la gentileza aristocrática, que asumía propia de los españoles, a la modernidad:

\begin{abstract}
¿Despertará algún día nuestro instinto comercial, colocándonos al nivel europeo, ó permaneceremos eternamente alejados de todos los grandes movimientos modernos? Esta postura solitaria y desdeñosa, podrá tener una cierta gentileza aristocrática; pero infortunadamente, no puede conservarse mucho tiempo ${ }^{104}$.
\end{abstract}

España debía participar de las formas modernas y europeas. En el fondo de todos estos argumentos latía la preocupación por probar ante el mundo civilizado que España podía ser también una potencia colonial exitosa: "Hay que demostrar á las demás naciones que sabemos colonizar y no olvidemos que los ojos del mundo civilizados están pendientes de nuestra labor en el Continente Africano"105.

Para lograr este objetivo, la hombría española necesitaba una reforma urgente. Los diversos autores dedicaban numerosas páginas a describir cómo debería ser el correcto hombre español colonial. Esta nueva masculinidad quedaba ejemplificada, en la obra de Ruiz Albéniz, en la figura de Berenguer, general que participó también en la guerra de Annual y que en este discurso se oponía a la imagen negativa de Silvestre. Berenguer era, en primer lugar, un hombre sereno y calmado "imperturbable, nunca airado, nunca descompuesto, siempre firme en un propósito de serenidad y justicia"106. Nunca perdía su "flema británica"107. Se trataba de un hombre discreto: "nunca quiso saber nada de populacherías, de las que tanto se abusa en España para fabricar hombres célebres y héroes populares"108. Otra cualidad adornaba a este hombre, la de no actuar "nunca de ligero", estudiando con detenimiento las acciones que debía llevar a cabo ${ }^{109}$. En estos relatos se proponía el hombre templado, autocontrolado y reflexivo "más habituado, que a manejar las armas, maneja mejor los libros y sobre el hombre de acción, impera el de estudio, de reflexión"110. El oficial colonial debía ser "modesto prudente y reservado"111. En contra del héroe impulsivo e irracional, "la energía debe ser la norma de nuestros actos, pero la energía recta, juiciosa, [...] sin actos de violencia" ${ }^{12}$. Este nuevo modelo de hombre colonial tenía otra noción del valor que se relacionaba con otro concepto del cuerpo masculino. En el militar heroico "el soplo de la muerte, la aurora del triunfo electriza y hacen poderoso y enérgico al más enclenque y desmedrado" "113. El peligro hacía posible la resistencia corporal. El cuerpo del nuevo hombre colonizador, en cambio, no resistía por la emoción de un momento de peligro, sino serenamente soportaba las penalidades durante años: "días, semanas, meses y años de continuada fatiga y privación, solo los recios de cuerpo

\footnotetext{
104 Muñoz, Isaac: La corte de..., p. 67.

105 Vázquez Sastre, Cayetano: En tierras del Rif..., p. 9.

106 Ruiz Albéniz, Víctor: Ecce homo..., p. 96.

107 Ruiz Albéniz, Víctor: Ecce homo..., p. 97.

108 Ruiz Albéniz, Víctor: Ecce homo..., p. 96.

109 Ruiz Albéniz, Víctor: Ecce homo..., p. 99.

110 Royo, Tomás: Allá, en el Rif..., p. 103.

111 Fuentes, Anatolino: Para el oficial de..., p. 48.

112 Vázquez Sastre, Cayetano: En tierras del Rif..., p. 51.

113 Ruiz Albéniz, Víctor: "Psicología de la oficialidad colonial”, Revista de Tropas Coloniales, 1 (1924), pp. 8-9.
} 
lo resisten"114. En esta propuesta, el hombre se caracterizaba además por la "rusticidad de aficiones y costumbres" ${ }^{115}$. No añoraba los placeres de la ciudad ni los cafés. Era un hombre austero, contenido con una rígida moral. Era culto, un buen conocedor de Marruecos y de sus habitantes ${ }^{116}$ y educaba a sus soldados y a los rifeños en lugar de tratarles de forma autoritaria ${ }^{117}$.

Todas estas cualidades masculinas correspondían a un concepto diferente de colonización, la acción en Marruecos "no tiene por finalidad exclusiva la de ganar batallas o rendir posiciones sino la de sumar voluntades y conquistar espíritus"118. En contraposición al ansia de conquista aguerrida "al heroísmo [...] debe adjuntarse y quizá sobreponerse la vocación" "119. Los buenos oficiales coloniales deben ser "los apóstoles del progreso" ". Al hombre que gustaba de la guerra, del uso de la fuerza bruta y la conquista se oponía el agente colonial laborioso que tiene "el espíritu constante en el trabajo, el cuidado constante de mejorar [...] el culto a la iniciativa y a la responsabilidad"121. En definitiva, la masculinidad no se lograba demostrando agresividad y un valor emocional y corporal, sino que se alcanzaba cuando el hombre, a través del trabajo y la vocación, contribuía al progreso y a la civilización: "Todo hombre en su tránsito por el mundo debe dejar su rastro en granos que se amontonarán en el granero de la civilización" 122.

Este modelo masculino se concretaba finalmente en una figura que encarnaba la nueva forma de colonización española: el padre ${ }^{123}$. El padre colonial debía instruir al pueblo colonizado, enseñarle, guiarle. "En Marruecos nuestra labor no puede ni debe ser de conquista [...] seremos los educadores, los guías"124.

Venimos á educar a una raza, á prepararla para la lucha del saber, ese pugilato y amor propio que tienen todos los pueblos civilizados porque sus hijos brillen en la historia del adelanto ${ }^{125}$.

El colonizador-padre se caracterizaba por la superioridad intelectual y el conocimiento científico frente a los rifeños, que como niños permanecían abrumados por tal inteligencia: "El rifeño no desprecia, sino que admira y hasta teme demasiado el

114 Ruiz Albéniz, Víctor: "Psicología de la...”, p. 9.

115 Ruiz Albéniz, Víctor: "Psicología de la ...", p. 9.

116 Fuentes, Anatolino: Para el oficial de policía indígena, Tetuán, La Papelera Africana, 1920, p. 26.

117 Fuentes, Anatolino: Para el oficial de..., p. 9.

118 Camba, Alberto: Alma mora, ..., p. 9.

119 Ruiz Albéniz, Víctor: Ecce homo..., p. 9.

120 Vázquez Sastre, Cayetano: En tierras del Rif..., p. 7.

121 Fuentes, Anatolino: Para el oficial de..., p. 19.

122 Vázquez Sastre, Cayetano: En tierras del Rif..., p. 8.

123 La imagen del padre colonial -y también la del misionero- podrían evocar figuras colonizadoras anteriores al discurso y periodo colonial estudiado caracterizadas por una afirmación de poder jerárquico y autoritario y en algunos casos con connotaciones religiosas. Para el contexto analizado, con esta imagen paternal del colonizador nos referimos, en cambio, al modelo de tutor que asumía la responsabilidad del hombre civilizado de guiar hacia el progreso al pueblo colonizado atrasado, concebido como hijo o hermano menor, para diferenciarlo del modelo de hombre que conquista y vence al colonizado, entendido como enemigo. Para este modelo de agente civilizador paternal, véase: Dawson, Graham: Soldier Heroes: British Adventure, Empire, and the Imagining of Masculinities, Routledge, London, 1994.

124 Zozaya, Antonio: "Cara al fuego y la luz", La libertad, 5 de agosto de 1922, reproducido en Oteyza, Luis: Abdel-Krim..., p. 57.

125 Vázquez Sastre, Cayetano: En tierras del Rif..., p. 7. 
valer intelectual de los hombres civilizados" ${ }^{126}$. En sus descripciones, Ruiz Albéniz, como médico, adoptaba la postura paternalista de quien conoce las técnicas de la ciencia moderna frente a los conocimientos rudimentarios de los marroquíes: "los éxitos médicos fueron lo bastante para dar al tebib ${ }^{127}$ una autoridad cierta y seria. Temperamentos vírgenes, en ellos los medicamentos hacían verdaderos milagros" 128 . El nuevo oficial colonial debía ser por tanto un hombre culto, racional, conocedor de los avances científicos más punteros y "a la vez, diplomático, ingeniero, arquitecto, financiero, agricultor, economista, arabista y legislador" ${ }^{\prime 29}$. No debía imponerse por la fuerza sino con el ejemplo para que "compruebe el indígena nuestra superioridad en todos los órdenes, sin jactancias ni soberbias por nuestra parte"130.

El colonizador, como padre, podía y debía regañar a los rifeños como a un hijo que tiene un mal comportamiento. Ruiz Albéniz nos relata el episodio en que debe amenazar con castigos a los rifeños que producen demasiado alboroto:

si se retiene el sueldo de alguno de los trabajadores porque ha faltado al trabajo: incidente al canto de cerca de una hora; $y$ éste que coge su fusil y amenaza; y aquél que se pega con otro, y chau-chau, y gritería, y no entenderse y tener de continuo que amenazar (y aun a veces realizarlo) con suspender el pago, si las reclamaciones no $\operatorname{cesan}^{131}$.

En definitiva, el padre colonial debía llevar a cabo una tarea de

Domeñamiento [que] consiste [...] en conseguir que la idea de rebelión, que vendrá a menudo a atormentar esas cabezas locas de niños, no se presente en sus cerebros sin que sea inmediatamente rechazada ${ }^{132}$.

Los hombres colonizados presentados de forma desvirilizadora, como niños necesitados de disciplina y autoridad educadora, ayudaban a esta imagen del hombre colonizador como padre y tutor ${ }^{133}$.

Este nuevo hombre garantizaría que la nación se sintiera orgullosa y ella misma "se enjoye con nuevas perlas del progreso" ${ }^{34}$. Encarnaba por tanto una nación culta, paternal, representante de la ciencia, el conocimiento moderno y la razón, una nación que pertenecía de pleno derecho al grupo de las naciones pujantes y de progreso. Como es evidente, la figura del padre colonial era también otra forma de negociar la imagen peyorativa difundida sobre España ${ }^{135}$.

126 Ruiz Albéniz, Víctor: España en el Rif (1908-1921), Melilla, Biblioteca de Melilla, 1995 (1ª ed, 1921), p. 80, 1995.

127 Médico. Así era como los rifeños llamaban a Ruiz Albéniz, Tebib Arrumi, "médico cristiano". El autor firmaba algunas de sus obras con este nombre.

128 Ruiz Albéniz, Víctor: España en el ..., p. 50.

129 Fuentes, Anatolino: Para el oficial..., p. 18.

130 Camba, Alberto: Alma mora ..., p. 9.

131 Ruiz Albéniz, Víctor: Ecce homo..., p. 59.

132 Fuentes, Anatolino: Para el oficial de..., p. 9.

133 De esta manera, Ruiz Albéniz aparecía como el agente imperial civilizado, similar en algunos aspectos al que Dawson ha analizado para el colonialismo británico en la figura de Lawrence de Arabia. Buen conocedor del indígena y del país, se convirtió, en cierto modo, en el líder de la población local con su inteligencia y sus conocimientos científicos modernos. Véase: Dawson, Graham: Soldier Heroes....

134 Vázquez Sastre, Cayetano: En tierras del Rif..., p. 9.

135 Como podemos comprobar, esta tarea relacionada con la definición de la identidad nacional llevó a estos autores a defender un modelo concreto de hombre, en el marco de las incertidumbres que dominaban las relaciones de 


\section{Civilización, masculinidad, nación}

Los discursos coloniales fueron profusos en la descripción de los pueblos colonizados, pero fueron más importantes si cabe para la definición de las identidades nacionales metropolitanas. En el marco del discurso colonial sobre Marruecos se discutía la identidad nacional española en un aspecto muy concreto: en relación a las dicotomías civilización-barbarie, progreso-decadencia, asumidas de forma transversal por sectores ideológicos diferentes como decisivas en la caracterización de las naciones. Se negociaba así una asignación identitaria peyorativa y orientalizante que cuestionaba la pertenencia de España al mundo del progreso y la civilización. Diferentes arquetipos masculinos presentes en este contexto vehiculaban este proceso de definición de la identidad nacional.

El género se ha definido como un elemento decisivo en la construcción de identidades nacionales. Esta relación intrínseca se ha estudiado más ampliamente a través de la feminidad. Se ha analizado cómo las mujeres son concebidas a menudo no como individuos, sino como representantes simbólicas de toda la comunidad nacional ${ }^{136}$. En el contexto estudiado, hemos comprobado que la masculinidad es también fundamental en este sentido, y que a través del cuerpo y de los valores masculinos se discutía la identidad nacional. Diferentes conceptos de lo que debía ser la España colonial se definían a través de diferentes características viriles: la España caducamente imperial, atrasada y agresiva se presentaba a través de los atributos masculinos del arrojo, el valor irreflexivo e irracional casi corporal, el ansia por la lucha y la fuerza bruta o el autoritarismo. Se encarnaba en la figura del conquistador aguerrido. La figura del padre que tutela a un pueblo infantilizado representaba por el contrario, la España civilizada, que se explicaba a través de otras cualidades varoniles como la templanza, el cálculo y reflexión racional, la inteligencia, la serenidad, la cultura y la autoridad paternal. Estas eran las cualidades que debían definir la nación moderna, mesurada, situada del lado de la ciencia y el pensamiento racional. Un país alejado del despotismo oriental o de valores irracionales como el orgullo conquistador, que caracterizaban un imperio marroquí otrora glorioso pero ahora decadente, encarnado en la imagen del aristócrata árabe nostálgico. España debía civilizar, como padre y tutor a pueblos infantiles, en lugar de conquistar como un soldado impetuoso a pueblos enemigos ${ }^{137}$. De este modo, comprobamos cómo

género durante el primer tercio del siglo XX en España. El feminismo, los cambios en el papel social de las mujeres o la visibilidad de la homosexualidad hicieron tambalear los ideales de género heredados del pasado. Diversos modelos convivieron en la España del momento como respuesta a esta incertidumbre. Véase: Aresti, Nerea: Masculinidades en tela de juicio: hombre y género en el primer tercio del siglo XX, Madrid, Cátedra, 2010; Aresti, Nerea: Médicos, donjuanes y mujeres modernas: los ideales de feminidad y masculinidad en el primer tercio del siglo XX, Bilbao, Universidad del País Vasco, Servicio Editorial-Euskal Herriko Unibertsitatea, 2001; Aresti, Nerea: "Masculinidad y nación...". Los autores analizados, que anhelaban la España civilizada, defendieron un modelo de hombre cercano a lo que se consideraba el modelo europeo de varón civilizado: un hombre templado, culto, trabajador, autocontrolado, racional. La reivindicación de una España civilizada condicionó el modelo de masculinidad que se proponía. Un nuevo hombre español era necesario para la definición de una nueva España colonial.

136 Blom, Ida, Hagemann, Karen y Hall, Catherine: Gendered Nations...; Yuval Davis, Nira: Gender and....

137 Como hemos mencionado inicialmente, algunos estudios han argumentado que, a diferencia del resto de potencias coloniales, España no se situaba respecto a Marruecos en una posición de clara superioridad y que establecía una relación de cierta proximidad o identificación con la cultura africana, véase: Martínez Antonio, Francisco Javier: "Regeneracionismo, sanidad...”; Martínez, Francisco Javier y González, Irene (ed.): Regenerar España ...; Martín Márquez, Susan: Desorientaciones.... A través de este análisis de la masculinidad, hemos 
también a través de imágenes masculinas y del cuerpo de los hombres se construía y se hacía visible la nación.

En el marco del proyecto colonial español en Marruecos se discutía y se construía la identidad nacional a través de las representaciones de género. El discurso colonial analizado reivindicaba que España debía definirse como una nación moderna, de progreso y civilizada. Con ello dialogaba con el discurso que la estigmatizaba como semiafricana y decadente, en un proceso de reconstrucción identitaria llevado a cabo a través de la masculinidad. 